\title{
Cyclometallation of bis-benzimidazole derivatives with rhodium(III) halides
}

\author{
V. Gayathri, E.G. Leelamani, N.M.N. Gowda*, G.K.N. Reddy \\ Department of Chemistry, Bangalore University, Central College Campus, Bangalore 560001, India
}

Received 16 December 1998; accepted 27 April 1999

\begin{abstract}
Treatment of rhodium(III) halides with the N-heterocycles (LH), 1,3-bis(benzimidazolyl)benzene (bBzlH ${ }_{2}$ bzH; Ia) and its $\mathrm{N}$-methyl derivative $\left(\mathrm{bBzlMe} \mathrm{b}_{2} \mathrm{bzH}\right.$; Ib) in methanol gave halobridged binuclear cyclometallated products of the composition $\left[\mathrm{RhX} \mathrm{X}_{2} \mathrm{~L}\right]_{2}(\mathrm{X}=\mathrm{Cl}, \mathrm{Br}$ or I). The chloro complex undergoes halobridge cleavage reactions to yield several new mononuclear complexes of the types $\mathrm{RhCl}_{2}\left(\mathrm{bBzlH}_{2} \mathrm{bz}\right)\left(\mathrm{AsPh}_{3}\right), \quad \mathrm{RhCl}\left(\mathrm{bBzlH}_{2} \mathrm{bz}\right)\left(\mathrm{OClO}_{3}\right)\left(\mathrm{L}^{\prime} / \mathrm{N}-\mathrm{N}\right) \quad\left(\mathrm{L}^{\prime}=\mathrm{AsPh}_{3} ; \mathrm{N}-\mathrm{N}=2,2^{\prime}\right.$-bipyridine or 1,10-phenanthroline $)$ and the heterocycle bridged binuclear complexes of the composition $\left[\mathrm{RhCl}_{2}\left(\mathrm{bBzlH} \mathrm{H}_{2} \mathrm{bz}\right)\right]_{2}(\mu-\mathrm{N}-\mathrm{N})\left(\mathrm{N}-\mathrm{N}=\right.$ pyrazine or $4,4^{\prime}$-bipyridine $)$. Passage of $\mathrm{CO}$ through $\left[\mathrm{RhCl}_{2}\left(\mathrm{bBzlH} \mathrm{H}_{2} \mathrm{bz}\right)\right]_{2}$ in DMF yielded mononuclear carbonyl complex $\mathrm{RhCl}_{2}(\mathrm{CO})\left(\mathrm{bBzlH} \mathrm{H}_{2} \mathrm{bz}\right) \cdot 2 \mathrm{H}_{2} \mathrm{O}$. Treatment of carbonylated solution of rhodium trichloride with Ia produced non-cyclometallated mononuclear complex of the type $\left[\mathrm{Rh}(\mathrm{CO})_{2}\left(\mathrm{bBzlH}_{2} \mathrm{bzH}\right)\right] \mathrm{Cl}$. The complexes are characterised by ${ }^{1} \mathrm{H},{ }^{13} \mathrm{C}$ NMR, IR, Far-IR, electronic and FAB-mass spectral studies. (C) 1999 Elsevier Science Ltd. All rights reserved.
\end{abstract}

Keywords: Cyclometallation; Rhodium; 1,3-Bis(benzimidazolyl)benzene; 1,3-Bis( $N$-methylbenzimidazolyl)benzene; Binuclear complexes; Multidentate $\mathrm{N}$-heterocycles

\section{Introduction}

The chemistry of a variety of organorhodium complexes of several $\mathrm{N}$-heterocycles and their derivatives has been widely investigated in recent years [1-8]. However, a relatively small number of $\mathrm{N}$-heterocycles are observed to undergo cyclometallation to give five-membered metallocycles (II) [9-16]. Furthermore, the chemistry of cyclometallated complexes is gaining importance as such complexes have been successively used in organic synthesis, asymmetric synthesis, homogeneous catalysis, liquid crystals and photochemistry [17].

Cyclometallation of the N-heterocycles Ia and Ib could give rise to products corresponding to (i) mononuclear closed metallo-bicycle (IIIa; 2-metallation), (ii) mononuclear open metallo-monocycle (IIIb; 4- or 6-metallation), or (iii) binuclear open metallo-bicycle (IIIc; 4- and 6-metallation, or IIId, 2 and 4-, or 2 and 6-metallation), the coordination being symmetrical (IIIa, c) or unsymmetrical (IIIb, d).

*Corresponding author. Tel.: +91-80-221-1679; fax: +91-80-2211679 .
Williams et al. [18] have synthesised a trimer of the 6-metallated acetato palladium(II) complex (IIIb, R= $\mathrm{CH}_{3} ; \mathrm{M}=\mathrm{Pd}$ ) whose crystal structure has been established by X-ray crystallography, the pendant benzimidazole group serving as a donor to another cyclometallated palladium(II). In continuation of our recent publication [19] on the reactions of rhodium and iridium salts with multidentate N-heterocycles, herein we report cyclometallation reactions of rhodium(III) with bis(benzimidazole) derivatives (I).
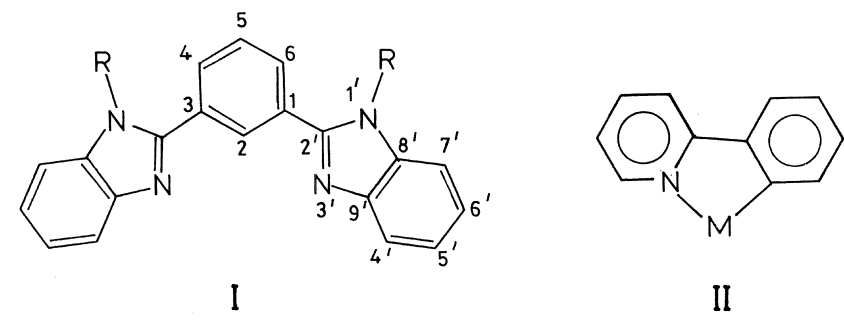

II
$\underline{R} \quad$ Abbreviation
(a) $\mathrm{H} \quad \mathrm{bBzIH}_{2} \mathrm{bzH}$
(b) $\mathrm{CH}_{3} \quad$ bBzIMe $2 \mathrm{bzH}$ 


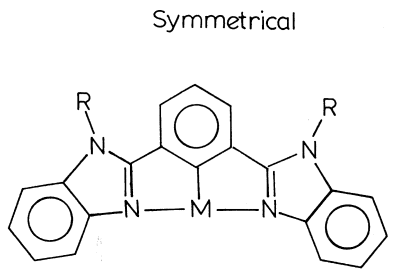

(a)

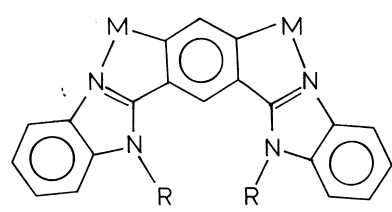

(c)

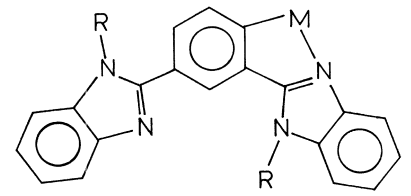

(b)

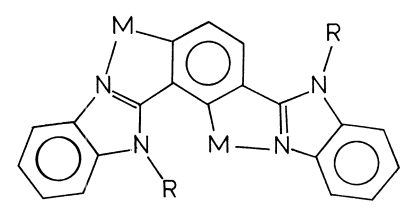

(d)
III

\section{Experimental}

\subsection{Materials}

The N-heterocycles bBzlH ${ }_{2}$ bzH and bBzlMe ${ }_{2}$ bzH were prepared according to a previously published report [20]. Rhodium trichloride was purchased from Arora-Matthey, India. Hydrated rhodium tribromide was prepared as described elsewhere [21].

\subsection{Physical measurement}

The IR spectra were recorded on a Carl-Zeiss SPECORD 75-IR and Nicolet FT-IR spectrometer. The electronic spectra were recorded on a Hitachi 150-20 spectrophotometer. The Far-IR spectra were recorded in polyethylene powder on a Bruker IFS 113V spectrophotometer. The ${ }^{1} \mathrm{H}$ and ${ }^{13} \mathrm{C}$ NMR spectra were recorded at ambient temperatures on a Bruker WH-270 and AMX-400 spectrometer with TMS as the internal reference. Rotating frame Overhauser effect spectroscopy (ROESY) experiments [22,23] were performed in DMSO$d_{6}$. A spin-lock mixing time of $250 \mathrm{~ms}$ was used. Nearly 512 FIDs were collected (each of 1024 complex data points) with $t_{1}$ incrementation. The resulting data were Fourier transformed along $F_{1}$ and $F_{2}$ dimensions with zero filling the $t_{1}$ data points to 1024 . The data were multiplied by squared sinebell window function shifted by $90^{\circ}$ on both $t_{2}$ and $t_{1}$ dimensions prior to Fourier transformation. ${ }^{1} \mathrm{H}$ and ${ }^{13} \mathrm{C}$ spin lattice $\left(T_{1}\right)$ relaxation measurements were performed using inversion recovery method. The FABmass spectra were recorded on a JEOL SX 102/DA-6000 mass spectrometer (using Xenon as the FAB gas and $m$-nitrobenzyl alcohol as the matrix) at CDRI, Lucknow, India. Microanalyses were obtained from 240B Perkin Elmer elemental analyser. The molar conductivities were determined using an Elico model CM-82T conductivity bridge with a conventional dip type conductivity cell.

\subsection{Preparation of the complexes}

\subsection{1. $\left[R h X_{2}\left(b B z l H_{2} b z\right)\right]_{2}$ and $\left[R h X_{2}\left(b B z l M e_{2} b z\right)\right]_{2}(X=$ $\mathrm{Cl}, \mathrm{Br}$ or I)}

Rhodium trichloride/bromide $(1 \mathrm{mmol})$ dissolved in methanol $\left(5 \mathrm{~cm}^{3}\right)$ was treated with a methanolic solution $\left(5 \mathrm{~cm}^{3}\right)$ of the N-heterocycle $(3 \mathrm{mmol})$. The mixture was heated under reflux for about $5 \mathrm{~h}$ during which a yellow or brown solid was separated. The solid was washed with methanol and dried in vacuo. Yield: $60-80 \%$.

Metathesis reaction of the chloro complexes with 15fold excess of sodium iodide on prolonged refluxing in methanol $(24 \mathrm{~h})$ gave yellowish-brown iodo complexes. Yield: $80 \%$.

\subsection{2. $\mathrm{RhCl}_{2}\left(b \mathrm{Bz} l \mathrm{H}_{2} b z\right)\left(\mathrm{AsPh}_{3}\right)$}

$\left[\mathrm{RhCl}_{2}\left(\mathrm{bBzlH}_{2} \mathrm{bz}\right)\right]_{2}(0.5 \mathrm{mmol})$ was treated with triphenyl arsine $(1 \mathrm{mmol})$ in methanol $\left(50 \mathrm{~cm}^{3}\right)$ and the mixture was refluxed for 2 days when a yellow solid got separated. It was washed with methanol and dried in vacuo. Yield: $50 \%$.

\subsection{3. $\mathrm{RhCl}\left(\mathrm{bBz} \mathrm{lH}_{2} b z\right)\left(\mathrm{L}^{\prime} / \mathrm{N}-\mathrm{N}\right)\left(\mathrm{OClO}_{3}\right)\left(\mathrm{L}^{\prime}=\mathrm{AsPh} h_{3} ; \mathrm{N}-\right.$ $N=$ bipy or phen)}

To a suspension of $\left[\mathrm{RhCl}_{2}\left(\mathrm{bBzlH}{ }_{2} \mathrm{bz}\right)\right]_{2}(1 \mathrm{mmol})$ in methanol $\left(50 \mathrm{~cm}^{3}\right)$, triphenyl arsine or $2,2^{\prime}$-bipyridine (bipy) or 1,10-phenanthroline (phen) $(2 \mathrm{mmol})$ and sodium perchlorate $(10 \mathrm{mmol})$ were added and the mixture was refluxed for $24 \mathrm{~h}$ when a yellow solid got separated. It was washed with methanol and water and dried in vacuo. Yield: $60 \%$.

\subsection{4. $\left[\mathrm{RhCl}_{2}\left(b \mathrm{Bz} l \mathrm{H}_{2} b z\right)\right]_{2}(\mu-N-N)(N-N=p y z$ or $b p y)$}

$\left[\mathrm{RhCl}_{2}\left(\mathrm{bBzlH}_{2} \mathrm{bz}\right)\right]_{2}(1 \mathrm{mmol})$ and pyrazine (pyz) or 4,4'-bipyridine (bpy) $(1 \mathrm{mmol})$ in methanol $\left(100 \mathrm{~cm}^{3}\right)$ were refluxed for $24 \mathrm{~h}$ when a yellow solid got separated. It was washed with methanol and dried in vacuo. Yield: $80 \%$.

\subsection{5. $\mathrm{RhCl}_{2}(\mathrm{CO})\left(b \mathrm{BzlH} \mathrm{H}_{2} b z\right) \cdot 2 \mathrm{H}_{2} \mathrm{O}$}

$\mathrm{CO}$ was bubbled through $\left[\mathrm{RhCl}_{2}\left(\mathrm{bBzlH}{ }_{2} \mathrm{bz}\right)\right]_{2}(1 \mathrm{mmol})$ suspended in dimethyl formamide $\left(10 \mathrm{~cm}^{3}\right)$ and heated to refluxing temperature. Gradually the complex dissolved to give a yellow solution. Passage of $\mathrm{CO}$ was continued for 6 $\mathrm{h}$ and the resultant solution was evaporated to dryness under reduced pressure when a yellow solid was obtained. It was washed with acetone and dried in vacuo. Yield: $60 \%$.

\subsection{6. $\left[\mathrm{Rh}(\mathrm{CO})_{2}\left(b \mathrm{BzlH} \mathrm{H}_{2} b z \mathrm{H}\right)\right] \mathrm{Cl}$}

$\mathrm{CO}$ was bubbled through an ethanolic solution $\left(10 \mathrm{~cm}^{3}\right)$ of rhodium trichloride $(1 \mathrm{mmol})$ at refluxing temperature 
until yellow. To this an ethanolic solution $\left(5 \mathrm{~cm}^{3}\right)$ of the heterocycle $(1 \mathrm{mmol})$ was added. Passage of $\mathrm{CO}$ was continued for about $2 \mathrm{~h}$ and the resultant solution was evaporated under $\mathrm{CO}$ atmosphere to a small volume when a light yellow solid got separated. The solid was washed quickly with acetone and dried in vacuo. Yield: $60 \%$.

\subsection{7. $\left[\mathrm{Rh}(\mathrm{CO})_{2}\left(b \mathrm{BzlH} \mathrm{H}_{2} b z \mathrm{H}\right)\right] \mathrm{ClO}_{4}$}

$\left[\mathrm{Rh}(\mathrm{CO})_{2}\left(\mathrm{bBzlH}_{2} \mathrm{bzH}\right)\right] \mathrm{Cl}(1 \mathrm{mmol})$ was suspended in methanol $\left(20 \mathrm{~cm}^{3}\right)$ and to this sodium perchlorate (2 mmol) was added. $\mathrm{CO}$ was passed through the mixture at refluxing temperature for $4 \mathrm{~h}$. The complex gradually dissolved to give a yellow solution. It was evaporated to dryness under reduced pressure to obtain a yellow solid. The resultant solid was washed with acetone followed by water and dried in vacuo. Yield: $60 \%$.

\section{Results and discussion}

The reaction of rhodium(III) halides with the multidentate N-heterocycles $(\mathbf{I}, \mathrm{LH})$ in methanol resulted in yellow dimeric complexes of the composition $\left[\mathrm{RhX}_{2} \mathrm{~L}\right]_{2}(\mathrm{X}=\mathrm{Cl}$ or $\mathrm{Br})$. Metathesis reaction of the chloro complex with sodium iodide in methanol produced the iodo analogues in a low state of purity. The complexes are diamagnetic and are insoluble in common organic solvents except for $\left[\mathrm{RhX}_{2}\left(\mathrm{bBzlH}_{2} \mathrm{bz}\right)\right]_{2}(\mathrm{X}=\mathrm{Cl}, \mathrm{Br}$ or I $)$ when dissolved in dimethyl formamide and dimethyl sulfoxide, result in solutions being non-conducting.

The solid state IR spectra of the complexes (Table 1) are comparable with those of the uncoordinated N-heterocycles barring minor shifts in the positions of the ligand bands. The NH stretching and N-Me deformation vibrations are observed around 3150 and $1415 \mathrm{~cm}^{-1}$, respec-

Table 1

Analytical and IR data of the complexes

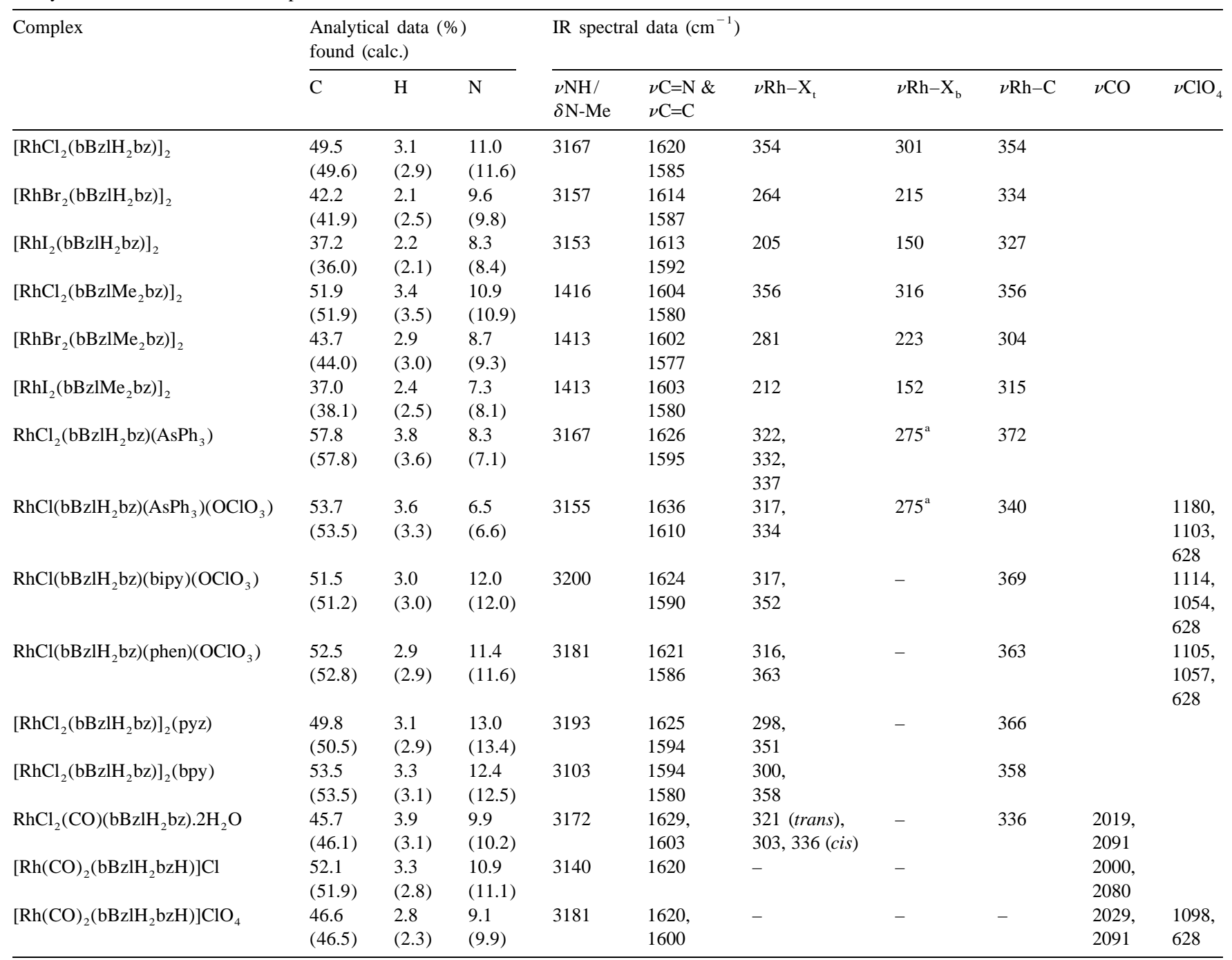

${ }^{\mathrm{a}} \nu \mathrm{Rh}-\mathrm{As}$. 
Table 2

${ }^{1} \mathrm{H}$ NMR spectral data in DMSO- $d_{6}(\delta \text { in ppm })^{\mathrm{a}, \mathrm{b}}$

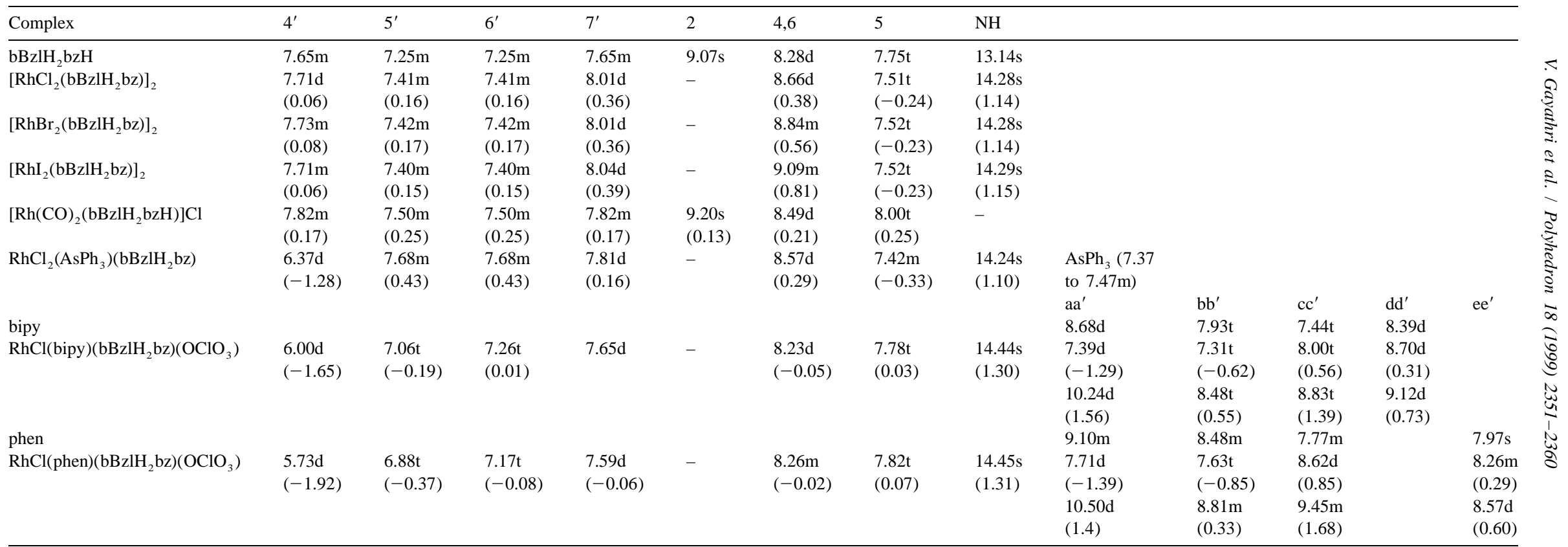

${ }^{\mathrm{a}}$ Values in parentheses are coordination induced shifts (c.i.s. $=\delta$ complex $-\delta$ ligand).

${ }^{\mathrm{b}} \mathrm{s}=$ singlet, $\mathrm{d}=$ doublet, $\mathrm{t}=$ triplet, $\mathrm{m}=$ multiplet. 
Table 3

${ }^{13} \mathrm{C}$ NMR spectral data in DMSO- $d_{6}(\delta \text { in } \mathrm{ppm})^{\mathrm{a}}$

\begin{tabular}{|c|c|c|c|c|c|c|c|c|c|c|c|c|c|c|c|c|c|}
\hline Complex & $2^{\prime}$ & $4^{\prime}$ & $5^{\prime}$ & $6^{\prime}$ & $7^{\prime}$ & $8^{\prime}$ & $9^{\prime}$ & 1,3 & 2 & 4,6 & 5 & & & & & & \\
\hline bBzlH ${ }_{2}$ bzH & 150.85 & 119.04 & 122.04 & 122.95 & 111.67 & 135.21 & 143.84 & 131.03 & 124.84 & 127.65 & 129.82 & & & & & & \\
\hline$\left[\mathrm{RhCl}_{2}\left(\mathrm{bBzlH} \mathrm{H}_{2} \mathrm{bz}\right)\right]_{2}$ & $\begin{array}{l}158.08 \\
(7.23)\end{array}$ & $\begin{array}{l}117.73 \\
(-1.31)\end{array}$ & $\begin{array}{l}123.57 \\
(1.53)\end{array}$ & $\begin{array}{l}123.80 \\
(0.85)\end{array}$ & $\begin{array}{l}112.77 \\
(1.10)\end{array}$ & $\begin{array}{l}133.10 \\
(-2.11)\end{array}$ & $\begin{array}{l}140.77 \\
(-3.07)\end{array}$ & $\begin{array}{l}132.77 \\
(1.74)\end{array}$ & $\begin{array}{l}181.63^{\mathrm{b}} \\
23.91^{\mathrm{c}} \\
(56.79)\end{array}$ & $\begin{array}{l}124.62 \\
(-3.03)\end{array}$ & $\begin{array}{l}124.31 \\
(-5.51)\end{array}$ & & & & & & \\
\hline$\left[\mathrm{RhBr}_{2}\left(\mathrm{bBzlH} \mathrm{bz}_{2}\right]_{2}\right.$ & $\begin{array}{l}158.34 \\
(7.49)\end{array}$ & $\begin{array}{l}118.30 \\
(-0.74)\end{array}$ & $\begin{array}{l}123.45 \\
(1.41)\end{array}$ & $\begin{array}{l}123.80 \\
(0.85)\end{array}$ & $\begin{array}{l}112.60 \\
(0.93)\end{array}$ & $\begin{array}{l}133.11 \\
(-2.10)\end{array}$ & $\begin{array}{l}141.14 \\
(-2.7)\end{array}$ & $\begin{array}{l}132.73 \\
(1.70)\end{array}$ & $\begin{array}{l}181.97^{\mathrm{b}} \\
24.45^{\mathrm{c}} \\
(57.13)\end{array}$ & $\begin{array}{l}124.70 \\
(-2.95)\end{array}$ & $\begin{array}{l}124.36 \\
(-5.46)\end{array}$ & & & & & & \\
\hline $\mathrm{RhCl}_{2}(\mathrm{CO})\left(\mathrm{bBzlH} \mathrm{H}_{2} \mathrm{bz}\right) \cdot 2 \mathrm{H}_{2} \mathrm{O}$ & $\begin{array}{l}150.65 \\
(-0.2)\end{array}$ & $\begin{array}{l}115.18 \\
(-3.86)\end{array}$ & $\begin{array}{l}122.96 \\
(0.92)\end{array}$ & $\begin{array}{l}122.96 \\
(0.01)\end{array}$ & $\begin{array}{l}115.18 \\
(3.51)\end{array}$ & $\begin{array}{l}138.78 \\
(3.57)\end{array}$ & $\begin{array}{l}138.78 \\
(-5.06)\end{array}$ & $\begin{array}{l}133.37 \\
(2.34)\end{array}$ & $\begin{array}{l}184.10^{\mathrm{b}} \\
20.0^{\mathrm{c}} \\
(59.26)\end{array}$ & $\begin{array}{l}129.97 \\
(2.32)\end{array}$ & $\begin{array}{l}130.30 \\
(0.48)\end{array}$ & \multicolumn{6}{|c|}{$\begin{array}{c}\text { (CO) } 181.51^{\mathrm{b}}, \\
79.9^{\mathrm{c}}\end{array}$} \\
\hline$\left[\mathrm{Rh}(\mathrm{CO})_{2}\left(\mathrm{bBzlH}{ }_{2} \mathrm{bzH}\right)\right] \mathrm{Cl}$ & $\begin{array}{l}148.95 \\
(-1.9)\end{array}$ & $\begin{array}{l}114.67 \\
(-4.37)\end{array}$ & $\begin{array}{l}124.86 \\
(2.82)\end{array}$ & $\begin{array}{l}124.86 \\
(1.91)\end{array}$ & $\begin{array}{l}114.67 \\
(3.0)\end{array}$ & $\begin{array}{l}135.01 \\
(-0.2)\end{array}$ & $\begin{array}{l}135.01 \\
(-8.83)\end{array}$ & $\begin{array}{l}127.30 \\
(-3.73)\end{array}$ & $\begin{array}{l}130.56 \\
(5.72)\end{array}$ & $\begin{array}{l}130.22 \\
(2.57)\end{array}$ & $\begin{array}{l}126.72 \\
(1.88)\end{array}$ & \multicolumn{6}{|c|}{$\begin{array}{c}\text { (CO) } 181.80^{\mathrm{b}} \\
72.62^{\mathrm{c}}\end{array}$} \\
\hline bipy & & & & & & & & & & & & $\begin{array}{l}\mathrm{aa}^{\prime} \\
149.07\end{array}$ & $\begin{array}{l}\mathrm{bb}^{\prime} \\
137.03\end{array}$ & $\begin{array}{l}\mathrm{cc}^{\prime} \\
120.29\end{array}$ & $\begin{array}{l}\mathrm{dd}^{\prime} \\
123.93\end{array}$ & $\begin{array}{l}\mathrm{ee}^{\prime} \\
155.18\end{array}$ & $\mathrm{ff}^{\prime}$ \\
\hline $\mathrm{RhCl}($ bipy $)\left(\mathrm{bBzlH}_{2} \mathrm{bz}\right)\left(\mathrm{OClO}_{3}\right)$ & $\begin{array}{l}158.15 \\
(7.30)\end{array}$ & $\begin{array}{l}113.31 \\
(-5.73)\end{array}$ & $\begin{array}{l}124.07 \\
(2.03)\end{array}$ & $\begin{array}{l}124.07 \\
(1.12)\end{array}$ & $\begin{array}{l}113.31 \\
(1.64)\end{array}$ & $\begin{array}{l}132.70 \\
(-2.51)\end{array}$ & $\begin{array}{l}139.42 \\
(-4.42)\end{array}$ & $\begin{array}{l}133.52 \\
(2.49)\end{array}$ & $\begin{array}{l}184.94^{\mathrm{b}} \\
22.28^{\mathrm{c}} \\
(60.1)\end{array}$ & $\begin{array}{l}125.21 \\
(-2.44)\end{array}$ & $\begin{array}{l}125.59 \\
(-4.23)\end{array}$ & $\begin{array}{l}151.68 \\
(2.61) \\
150.63 \\
(1.56)\end{array}$ & $\begin{array}{l}128.04 \\
(-8.99) \\
128.34 \\
(-8.69)\end{array}$ & $\begin{array}{l}139.96 \\
(19.67) \\
141.34 \\
(21.05)\end{array}$ & $\begin{array}{l}124.07 \\
(0.14)\end{array}$ & $\begin{array}{l}156.46 \\
(1.28) \\
154.59 \\
(-0.59)\end{array}$ & \\
\hline phen & & & & & & & & & & & & 149.94 & 136.19 & 126.66 & 128.45 & 123.30 & 145.54 \\
\hline $\mathrm{RhCl}($ phen $)\left(\mathrm{bBzlH}_{2} \mathrm{bz}\right)\left(\mathrm{OClO}_{3}\right)$ & $\begin{array}{l}158.29 \\
(7.44)\end{array}$ & $\begin{array}{l}113.34 \\
(-5.7)\end{array}$ & $\begin{array}{l}123.75 \\
(1.71)\end{array}$ & $\begin{array}{l}123.75 \\
(0.8)\end{array}$ & $\begin{array}{l}113.18 \\
(1.51)\end{array}$ & $\begin{array}{l}132.75 \\
(-2.46)\end{array}$ & $\begin{array}{l}139.64 \\
(-4.20)\end{array}$ & $\begin{array}{l}133.91 \\
(2.88)\end{array}$ & $\begin{array}{l}184.93^{\mathrm{b}} \\
22.71^{\mathrm{c}} \\
(60.09)\end{array}$ & $\begin{array}{l}125.34 \\
(-2.31)\end{array}$ & $\begin{array}{l}125.49 \\
(-4.33)\end{array}$ & $\begin{array}{l}152.64 \\
(2.7) \\
151.64 \\
(1.7)\end{array}$ & $\begin{array}{l}126.69 \\
(-9.5) \\
127.19 \\
(-9.0)\end{array}$ & $\begin{array}{l}139.02 \\
(12.36) \\
139.99 \\
(13.33)\end{array}$ & $\begin{array}{l}130.22 \\
(1.77) \\
130.50 \\
(2.05)\end{array}$ & $\begin{array}{l}127.80 \\
(4.5) \\
128.31 \\
(5.0)\end{array}$ & $\begin{array}{l}146.77 \\
(1.23) \\
145.49 \\
(-0.05)\end{array}$ \\
\hline
\end{tabular}

\footnotetext{
${ }^{a}$ Values in parentheses are coordination induced shifts (c.i.s. $=\delta$ complex $-\delta$ ligand).

${ }^{\mathrm{b}}$ Doublet.

c $J_{\mathrm{Rh}-\mathrm{C}}$ in $\mathrm{Hz}$.
} 
tively and are suggestive of the coordination of the $\mathrm{N}$ heterocycles to the metal ion via the tertiary nitrogens. The Far-IR spectra of the complexes displayed peaks corresponding to rhodium-halogen stretches and are indicative of the presence of both terminal and bridged types of halides [24]. The spectra also displayed a peak due to $\nu \mathrm{Rh}-\mathrm{C}$ in the range $300-360 \mathrm{~cm}^{-1}$; the result pointing to cyclometallation [25] of the bis-benzimidazole derivative. Cyclometallation is further supported by the ${ }^{1} \mathrm{H}$ and ${ }^{13} \mathrm{C}$ NMR spectra of the complexes and also the FAB-mass spectra.

The PMR spectra of $\mathrm{bBzlH}_{2} \mathrm{bzH}$ and $\left[\mathrm{RhX}_{2} \mathrm{~L}\right]_{2}$ in DMSO- $d_{6}$ (Table 2) exhibited resonances due to the central benzene and the benzimidazole ring protons. The resonance due to the imine proton is observed around $14 \delta$. The resonance at $9.07 \delta$ arising from the proton on carbon-2 of the central benzene/phenylene ring of the un-coordinated heterocycle $\mathrm{bBzlH}_{2} \mathrm{bzH}$ is absent in the spectra of the complexed species. Furthermore, the ${ }^{13} \mathrm{C}$ resonance of C-2 which appeared as a singlet at $129.82 \delta$ for the free heterocycle is split into a doublet [26-28] and has shifted downfield by nearly $50 \delta$ on complexation (Table 3). The splitting is due to the interaction of ${ }^{13} \mathrm{C}$ with ${ }^{103} \mathrm{Rh}(100 \%, I=1 / 2)$ the coupling constant being 24 $\mathrm{Hz}$ is diagnostic of rhodium-carbon direct linkage. The resonances due to C-4' and C-9' of bBzlH ${ }_{2}$ bz unit have undergone an upfield shift on complexation.

The FAB-MS of $\left[\mathrm{RhCl}_{2} \mathrm{~L}\right]_{2} \quad\left(\mathrm{LH}=\mathrm{bBzlH}_{2} \mathrm{bzH}\right)$ has confirmed the dinuclear nature of the complex. The spectrum showed a parent ion peak at $m / z 966\left[\mathrm{M}^{+}+2 \mathrm{H}\right]$. The parent ion loses $\mathrm{Cl}, \mathrm{HCl}$ or $[\mathrm{HCl}+\mathrm{H}]$ to give peaks at $m / z$ 931, 930 and 929, respectively. These further lose $(\mathrm{HCl}+\mathrm{H}), \mathrm{HCl}$ or $\mathrm{Cl}$, respectively to give a peak at $\mathrm{m} / \mathrm{z}$ 894 due to $\mathrm{Rh}_{2} \mathrm{Cl}_{2} \mathrm{~L}_{2}$. Subsequent fragmentation produced the mononuclear species $\mathrm{RhL}_{2}$ (by loss of $\mathrm{RhCl}+\mathrm{Cl}$ ) and $\mathrm{RhClL}$ (due to loss of RhClL). These molecular ions lose $\mathrm{L}$ or $\mathrm{Cl}$, respectively, to give $\mathrm{RhL}(\mathrm{m} / z 412)$, which in turn loses $(\mathrm{Rh}+2 \mathrm{H})$ to give a peak $(\mathrm{L}-2 \mathrm{H})$ at $\mathrm{m} / z$ 307. The fragmentation reactions are summarised in Scheme 1.

The electronic spectra of $\left[\mathrm{RhX}_{2} \mathrm{~L}\right]_{2}$ exhibited weak absorption bands in the range 400-500 $\mathrm{nm}$ (Table 4) and are ascribed to $d-d$ transitions of octahedral spin paired $d^{6}$ system [29]. An intense peak at $370 \mathrm{~nm}$ is attributed to metal-to-ligand charge transfer transition.

The N-heterocycles can serve as bidentate or tridentate ligands. Earlier, it has been observed that the heterocycles have displayed a bidentate non-cyclometallated behaviour [20] in $\mathrm{CoX}_{2}(\mathrm{LH})(\mathrm{X}=\mathrm{Cl}, \mathrm{Br}$ or $\mathrm{I} ; \mathrm{LH}=\mathbf{I a}$ or $\mathbf{I b})$ and $\mathrm{Co}(\mathrm{LH})_{2}\left(\mathrm{ClO}_{4}\right)_{2}$ complexes and a bridging tridentate cyclometallated behaviour in $\left[\mathrm{PdL}\left(\mathrm{OOCCH}_{3}\right)\right]_{3} \cdot 9 \mathrm{CH}_{3} \mathrm{CN}$ complex [18]. In the present investigation a tridentate behaviour of the N-heterocycles $(\mathrm{N}-\mathrm{C}-\mathrm{N})$ leading to nonbridging cyclometallation but dihalobridged binuclear nature has been observed. Considering the $\mathrm{N}$-heterocycles as planar and by taking the $\mathrm{N}-\mathrm{C}-\mathrm{N}$ skeleton, two structures can be conceived for such complexes, the one being

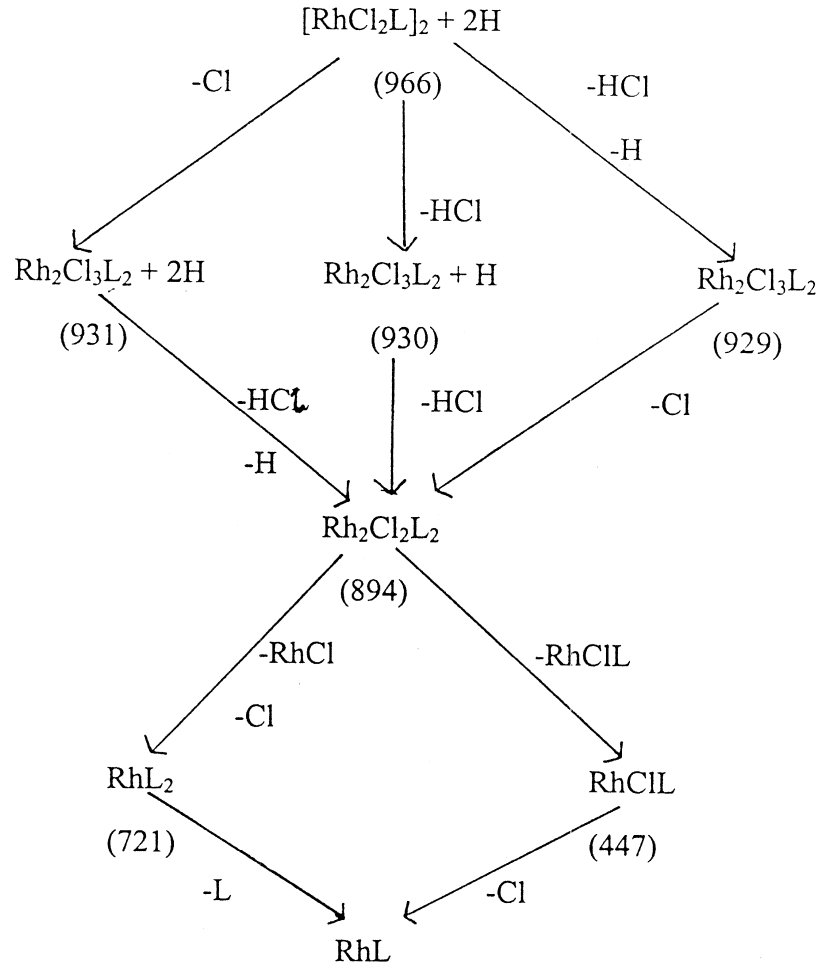

(412)<smiles>[Y]C(C)CCCCC</smiles>

(307)

Scheme 1. Fragmentation pathway of $\left[\mathrm{RhCl}_{2} \mathrm{~L}\right]_{2}$.

centrosymmetric (trans, IVa) and the other being noncentrosymmetric ( $c i s, \mathbf{I V b})$. Molecular models favour the former (IVa) which has less steric hindrance than the latter. Further with both in the ${ }^{1} \mathrm{H}$ and ${ }^{13} \mathrm{C}$ NMR spectra, only one set of resonances have been observed implying the chemical equivalence of the corresponding protons as well as the carbons of the two heterocycles in each of the binuclear complexes.

The complex $\left[\mathrm{RhCl}_{2}\left(\mathrm{bBzlH}{ }_{2} \mathrm{bz}\right)\right]_{2}$ undergoes halobridge cleavage reaction. It reacts with $\mathrm{AsPh}_{3}$ in methanol at refluxing temperature to give a monomeric complex $\mathrm{RhCl}_{2}\left(\mathrm{bBzlH}_{2} \mathrm{bz}\right)\left(\mathrm{AsPh}_{3}\right)(\mathbf{V})$. In the presence of excess of sodium perchlorate, complex of the type $\mathrm{RhCl}\left(\mathrm{bBzlH}_{2} \mathrm{bz}\right)\left(\mathrm{AsPh}_{3}\right)\left(\mathrm{OClO}_{3}\right)$ has been isolated. The dimer $\left[\mathrm{RhCl}_{2}\left(\mathrm{bBzlH}{ }_{2} \mathrm{bz}\right)\right]_{2}$ reacts with chelating bidentate ligands like 2,2'-bipyridine (bipy) and 1,10-phenanthroline (phen) in the presence of excess of sodium perchlorate to form yellow crystalline monomeric complexes of the type $\mathrm{RhCl}\left(\mathrm{bBzlH}_{2} \mathrm{bz}\right)(\mathrm{N}-\mathrm{N})\left(\mathrm{OClO}_{3}\right)(\mathrm{VI})(\mathrm{N}-\mathrm{N}=$ bipy or phen $)$. On the other hand with bridging bidentate ligands, $\left[\mathrm{RhCl}_{2}\left(\mathrm{bBzlH}_{2} \mathrm{bz}\right)\right]_{2}$ in methanol yielded complexes of the type $\left[\mathrm{RhCl}_{2}\left(\mathrm{bBzlH}_{2} \mathrm{bz}\right)\right]_{2}(\mu-\mathrm{N}-\mathrm{N}) \quad(\mathrm{VII}) \quad(\mathrm{N}-\mathrm{N}=$ pyrazine 
Table 4

Electronic spectral data in DMF (nm)

\begin{tabular}{|c|c|c|c|}
\hline \multirow[t]{2}{*}{ Complex } & \multicolumn{3}{|c|}{ Electronic transitions ${ }^{a}$} \\
\hline & Ligand bands & $\begin{array}{l}\mathrm{M} \rightarrow \mathrm{L} \\
\text { Charge transfer } \\
\text { Transition }\end{array}$ & $\mathrm{d} \rightarrow \mathrm{d}$ transitions \\
\hline $\mathrm{bBzlH}_{2} \mathrm{bzH}$ & $\begin{array}{l}300(44231) \\
309(51442) \\
324(35817) \\
335(2599)\end{array}$ & & \\
\hline$\left[\mathrm{RhBr}_{2}\left(\mathrm{bBzlH}{ }_{2} \mathrm{bz}\right)\right]_{2}$ & $304(37409)$ & $\begin{array}{l}367(12863) \\
384(11593)\end{array}$ & $\begin{array}{l}\text { 405(737),434(208), } \\
\text { 475(83), 548(18) }\end{array}$ \\
\hline$\left[\mathrm{RhI}_{2}\left(\mathrm{bBzlH} \mathrm{H}_{2} \mathrm{bz}\right)\right]_{2}$ & $\begin{array}{l}299(28333) \\
310(29925) \\
325(22895) \\
340(16855)\end{array}$ & $\begin{array}{l}373(11391) \\
386(8358)\end{array}$ & $459(266), 591(27)$ \\
\hline $\mathrm{RhCl}\left(\mathrm{bBzlH}{ }_{2} \mathrm{bz}\right)\left(\mathrm{AsPh}_{3}\right)\left(\mathrm{OClO}_{3}\right)$ & $\begin{array}{l}308(43478) \\
338(28225) \\
343(24792)\end{array}$ & $\begin{array}{l}396(4512) \\
388(7406)\end{array}$ & 439(58), 469(71) \\
\hline $\mathrm{RhCl}\left(\mathrm{bBzlH} \mathrm{H}_{2} \mathrm{bz}\right)(\mathrm{bipy})\left(\mathrm{OClO}_{3}\right)$ & $\begin{array}{l}297(30027) \\
360(18283)\end{array}$ & $\begin{array}{l}388(9835) \\
398(3004)\end{array}$ & 418(905), 466(42) \\
\hline $\mathrm{RhCl}\left(\mathrm{bBzlH}_{2} \mathrm{bz}\right)(\mathrm{phen})\left(\mathrm{OClO}_{3}\right)$ & $\begin{array}{l}278(30425) \\
292(29621) \\
358(18703)\end{array}$ & $\begin{array}{l}389(9162) \\
397(3759)\end{array}$ & $447(66), 466(31)$ \\
\hline$\left[\mathrm{RhCl}_{2}\left(\mathrm{bBzlH}{ }_{2} \mathrm{bz}\right)\right]_{2}(\mathrm{pyz})$ & $\begin{array}{l}304(53888) \\
367(24078)\end{array}$ & $\begin{array}{l}386(23056) \\
392(1200) \\
394 \operatorname{sh}(11341)\end{array}$ & $439(258), 471(94)$ \\
\hline
\end{tabular}

${ }^{\mathrm{a}} \epsilon$ values are in parentheses.

(pyz) or 4,4'-bipyridyl (bpy)). A similar reaction with phenazine also produced a binuclear complex, though in a low state of purity. Reaction of $\mathrm{CO}$ with $\left[\mathrm{RhCl}_{2}\left(\mathrm{bBzlH}_{2} \mathrm{bz}\right)\right]_{2}$ in dimethylformamide at refluxing temperature gave monomeric yellow rhodium(III) carbonyl complex of the composition $\mathrm{RhCl}_{2}(\mathrm{CO})\left(\mathrm{bBzlH}_{2} \mathrm{bz}\right) \cdot 2 \mathrm{H}_{2} \mathrm{O}$ (VIII).

The complexes are insoluble in common organic solvents but soluble in dimethyl formamide or dimethyl sulfoxide in which the solutions are non-conducting. The physical properties and analytical data of the complexes are listed in Table 1.

The complexes exhibit $\nu \mathrm{NH}$ in the range 3100-3200 $\mathrm{cm}^{-1}$ as a broad peak. The perchlorate complexes (being non-electrolytes in DMSO/DMF) in addition to the heterocycle bands exhibit peaks around 1100 and 628 $\mathrm{cm}^{-1}$, the former peak is split indicating the coordination of perchlorate to the metal ion [30]. In view of the above, it is likely that the heterocycle bipy or phen is behaving as a monodentate rather than bidentate ligand. This is sup- ported by ${ }^{1} \mathrm{H}$ and ${ }^{13} \mathrm{C}$ NMR spectra of the complexes. The carbonyl complex exhibits two intense $\nu \mathrm{CO}$ peaks at 2019 and $2091 \mathrm{~cm}^{-1}$ indicating the presence of two isomers (VIII; CO trans to $\mathrm{Cl}$ and trans to C). The Far-IR spectra of the complexes exhibit peaks corresponding to $\nu \mathrm{M}-\mathrm{Cl}$, $\nu \mathrm{M}-\mathrm{N}$ and $\nu \mathrm{M}-\mathrm{C}$, and are diagnostic of terminal halides.

The ${ }^{1} \mathrm{H}$ NMR spectra of the complexes displayed peaks

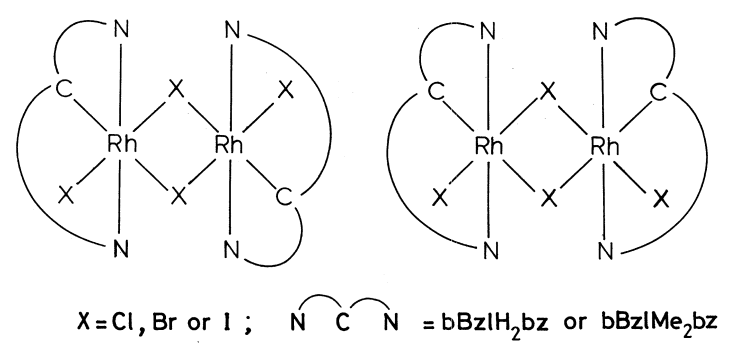

(a)

(b)

IV 


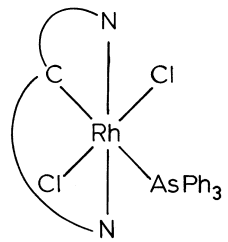

(a)

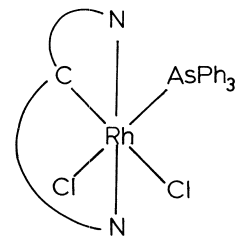

(b)

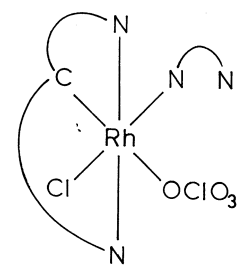

(a)

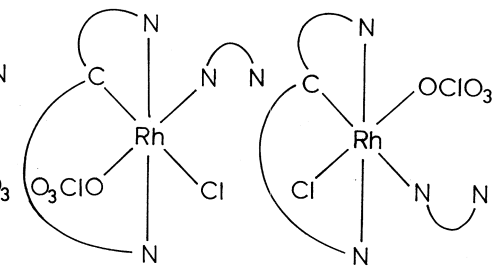

(b)

VI

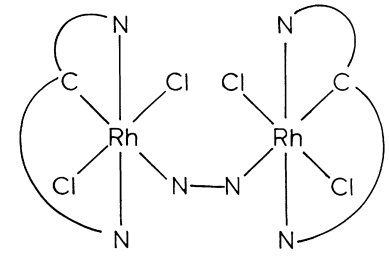

(a)

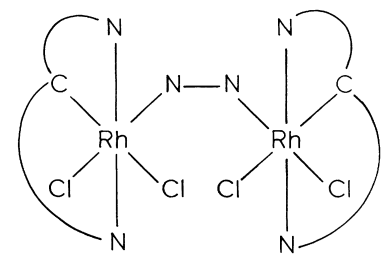

(b)

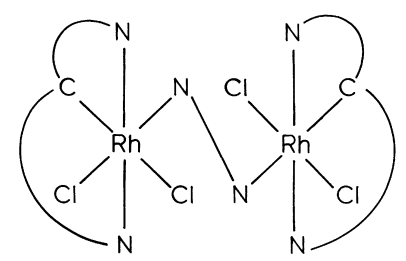

(c)

VII

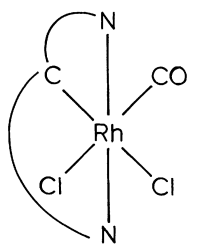

(a)

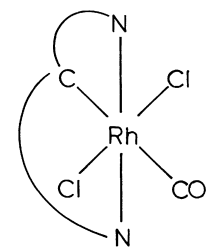

(b)
VIII

due to $\mathrm{bBzlH}_{2} \mathrm{bz}$ and the substituted ligands. The resonance due to the imine proton is observed around $14 \delta$. The resonance of $\mathrm{H}-4^{\prime}$ of $\mathrm{bBzlH}_{2} \mathrm{bz}$ has undergone an upfield shift as compared to that of the parent complex. A negative c.i.s. has been observed and this is probably due to metalto-ligand $\pi$-back donation [31]. Interestingly the ${ }^{1} \mathrm{H}$ and ${ }^{13} \mathrm{C}$ NMR spectra of the complexes $\mathrm{RhCl}\left(\mathrm{bBzlH}_{2} \mathrm{bz}\right)(\mathrm{N}$ $\mathrm{N})\left(\mathrm{OClO}_{3}\right)(\mathrm{N}-\mathrm{N}=$ bipy or phen $)$ exhibited two sets of resonances due to bipy or phen (Figs. 1 and 2). One set of proton resonances in the upfield region assignable to the uncoordinated part of the heterocycle and the other set in the downfield region to the coordinated part. Surprisingly, the heterocycle, bipy or phen is neither chelating nor bridging bidentate in the complexes. Such a coordination with pendant nitrogen is rather unusual in organometallic chemistry. The monodentate behaviour of bipy or phen in the complexes is also supported by ROESY measurements. The ROESY spectra of the complexes have revealed the interaction of all the protons $\left(\mathrm{a}^{\prime}\right.$ to $\left.\mathrm{d}^{\prime}\right)$ of the coordinated part of bipy or phen with $\mathrm{H}-4^{\prime}$ of $\mathrm{bBzlH}_{2}$ bz as evidenced by the interligand NOE measurements. The $\mathrm{H}-4^{\prime}$ shows NOE to $\mathrm{a}^{\prime}, \mathrm{b}^{\prime}, \mathrm{c}^{\prime}$ and $\mathrm{d}^{\prime}$ in the bipy complex and $\mathrm{a}^{\prime}, \mathrm{b}^{\prime}$ and $c^{\prime}$ in the phen complex. The results indicate that the coordinated part of the bipy or phen is much closer to $\mathrm{bBzlH}_{2} \mathrm{bz}$ than the uncoordinated part. The spin lattice relaxation times of the protons and carbons of the coordinated part of the bipy in $\mathrm{RhCl}\left(\mathrm{bBzlH}_{2} \mathrm{bz}\right)($ bipy $)\left(\mathrm{OClO}_{3}\right)$ are observed to be lower compared to those of the uncoordinated part implying more flexibility of the latter unit. Detailed 2D NMR studies on the complexes are in progress. The monodentate behaviour of the ligand may be attributed to the electronic factor rather than the steric hindrance around the metal ion. The complexes exhibit negative c.i.s. values for $\mathrm{C}-4^{\prime}$ and $\mathrm{C}-9^{\prime}$ of $\mathrm{bBzlH}_{2} \mathrm{bz}$. The ${ }^{13} \mathrm{C}$ NMR spectrum of the carbonyl complex displayed two doublets one at 182 and the other at $184 \delta$. The ${ }^{103} \mathrm{Rh}-$ ${ }^{13} \mathrm{C}$ coupling constant of the former is $80 \mathrm{~Hz}$ (due to $\mathrm{Rh}-\mathrm{CO}$ ) whereas that of the latter is $20 \mathrm{~Hz}$ (due to $\mathrm{Rh}-\mathrm{C}-2$ of $\mathrm{bBzlH}_{2} \mathrm{bz}$ ).

The FAB-MS of $\mathrm{RhClL}(\mathrm{N}-\mathrm{N})\left(\mathrm{OClO}_{3}\right) \quad(\mathrm{LH}=$ $\mathrm{bBzlH}_{2} \mathrm{bzH}$ ) have confirmed the mononuclear nature of the complexes. The spectra consist of molecular ion peaks at $\mathrm{m} / \mathrm{z} 702(\mathrm{~N}-\mathrm{N}=$ bipy $)$ and $726(\mathrm{~N}-\mathrm{N}=$ phen $)$. Both the complexes first lose perchlorate to produce $\operatorname{RhClL}(\mathrm{N}-\mathrm{N})$ and then $\mathrm{Cl}$ to give $\mathrm{RhL}(\mathrm{N}-\mathrm{N})$. Subsequent loss of N-N gives $\mathrm{RhL}(m / z$ 412). Both $\mathrm{RhL}(\mathrm{N}-\mathrm{N})$ and $\mathrm{RhL}$ lose $\mathrm{Rh}+2 \mathrm{H}$ to give a ligand peak at $\mathrm{m} / \mathrm{z}$ 307. In the case of the FAB-MS of $\left[\mathrm{RhCl}_{2}\left(\mathrm{bBzlH}{ }_{2} \mathrm{bz}\right)\right]_{2}(\mu$-bpy $)$ the molecular ion peak corresponding to the $\operatorname{dimer}(\mathrm{m} / \mathrm{z}, 1120)$ was not observed, but the peaks due to the fragmentation products $\mathrm{RhClL}_{2}(m / z 757), \mathrm{RhL}_{2}(m / z$ 712), $\mathrm{RhClL}(\mathrm{m} / z$ $447)$ and $\mathrm{Rh}\left(\mathrm{bBzlH}_{2} \mathrm{bz}\right)(\mathrm{m} / \mathrm{z} 412)$ were observed.

A dicarbonyl complex of rhodium(I) $\mathrm{RhCl}(\mathrm{CO})_{2}\left(\mathrm{bBzlH}_{2} \mathrm{bzH}\right)$ as a light yellow solid was isolated by treating an alcoholic carbonylated solution of rhodium trichloride with $\mathrm{bBzlH}_{2} \mathrm{bzH}$. In the case of bBzlMe ${ }_{2}$ bzH, a blue coloured dicarbonyl ( $\nu \mathrm{CO}, 1993$ and $2068 \mathrm{~cm}^{-1}$ ) of low state of purity was obtained. The chloro carbonyl is insoluble in nitrobenzene and acetonitrile but soluble in dimethyl formamide and alcohol in which its electrolytic behaviour is uni-univalent.

The IR spectrum of the chloro carbonyl in addition to the ligand peaks exhibited two intense peaks around 2000 and $2080 \mathrm{~cm}^{-1}$ due to $\nu \mathrm{CO}$. The $\nu \mathrm{NH}$ of the coordinated heterocycle is observed at $3140 \mathrm{~cm}^{-1}$. The complex has not undergone metallation reaction as evidenced by its ${ }^{1} \mathrm{H}$ and ${ }^{13} \mathrm{C}$ NMR spectra. The PMR spectrum has displayed a 


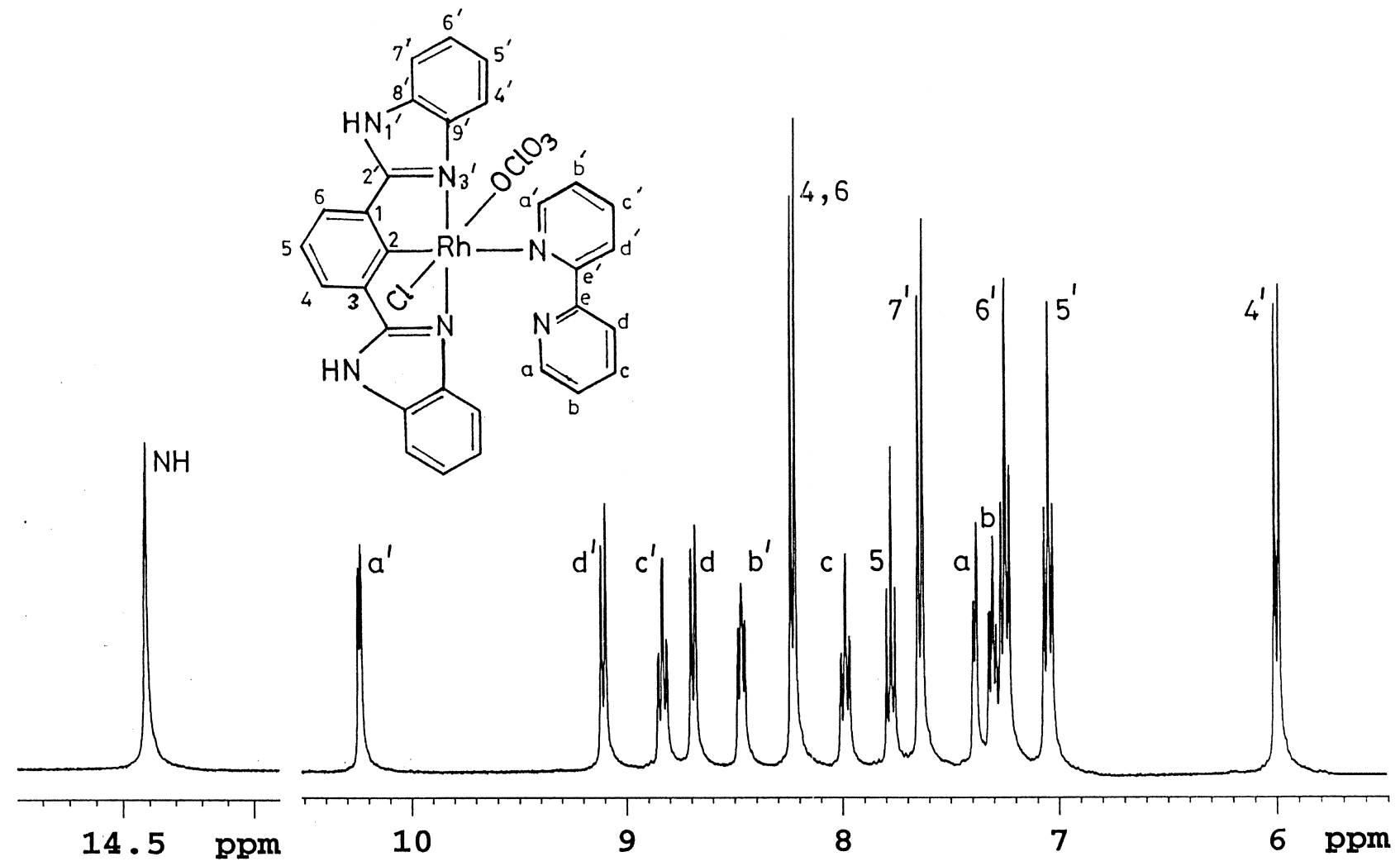

Fig. 1. ${ }^{1} \mathrm{H}$ NMR spectrum of $\mathrm{RhCl}\left(\mathrm{bBzlH} \mathrm{H}_{2} \mathrm{bz}\right)(\mathrm{bipy})\left(\mathrm{OClO}_{3}\right)$.
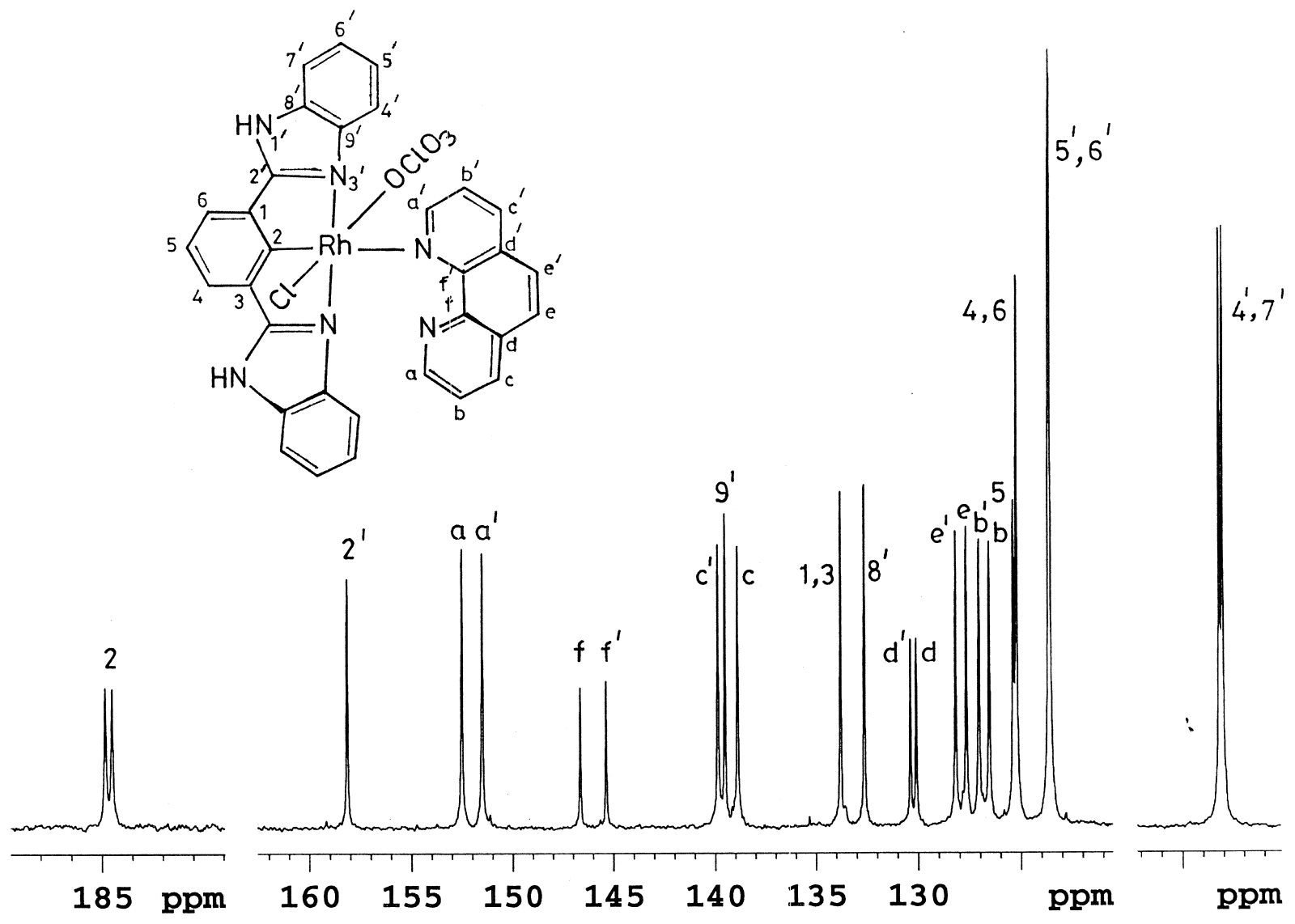

Fig. $2 .{ }^{13} \mathrm{C}$ NMR spectrum of $\mathrm{RhCl}\left(\mathrm{bBzlH}_{2}\right.$ bz) $($ phen $)\left(\mathrm{OClO}_{3}\right)$. 


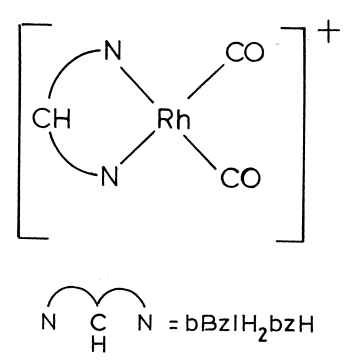

IX

singlet at $9.20 \delta$ corresponding to the proton on carbon-2. The imine proton resonance is not observed and is probably too broad owing to rapid exchange of this proton with those of water in the solvent. In the ${ }^{13} \mathrm{C}$ NMR spectrum a peak due to $\mathrm{C}-2$ of $\mathrm{bBzlH}_{2}$ bzH is observed at $126.7 \delta$. This has not shifted appreciably as compared to that of the free heterocycle. Furthermore the peak is not split implying non-metallation. However, a doublet resonance at $181 \delta$ due to the carbonyl with a $\mathrm{Rh}-\mathrm{C}$ coupling constant of $73 \mathrm{~Hz}$ has been observed. The FAB-MS of $\mathrm{RhCl}(\mathrm{CO})_{2}\left(\mathrm{bBzlH}_{2} \mathrm{bzH}\right)$ has revealed mononuclear nature of the complex. The spectrum displayed a parent ion peak at $m / z, 505\left(\mathrm{M}^{+}+\mathrm{H}\right)$. Loss of the carbonyl groups and $\mathrm{HCl}$ produced $\mathrm{Rh}(\mathrm{LH})(\mathrm{m} / \mathrm{z} 413)$. Further loss of Rh occurs to give $\mathrm{L}+\mathrm{H}(m / z 311)$.

The carbonyl complex is cationic in nature. The ionic chloride can be replaced by perchlorate by suspending the complex in alcohol in the presence of sodium perchlorate in $\mathrm{CO}$ atmosphere. The IR spectrum of the resultant complex $\left[\mathrm{Rh}(\mathrm{CO})_{2}\left(\mathrm{bBzlH}_{2} \mathrm{bzH}\right)\right] \mathrm{ClO}_{4}$ exhibited two $\nu \mathrm{CO}$ peaks (2029 and $2091 \mathrm{~cm}^{-1}$ ) and also peaks due to ionic perchlorate [30] $\left(1098\right.$ and $\left.628 \mathrm{~cm}^{-1}\right)$. Based on the above results a square planar structure (IX) wherein the heterocycle would function as bidentate has been proposed for the complex cation.

\section{Acknowledgements}

The authors are thankful to the UGC, New Delhi for the DRS programme, Professor C.L. Khetrapal and G.A. Nagana Gowda, SIF and Dr H.S. Vasan, SSCU, IISc, Bangalore for NMR and Far-IR spectra. The authors are also indebted to the referees for valuable suggestions.

\section{References}

[1] M.P. Garcia, J.L. Millan, M.A. Esteruelas, L.A. Oro, Polyhedron 6 (1987) 1427.

[2] M.A. Garcia, M.A. Garralda, L. Ibarlucea, Polyhedron 7 (1988) 1067.

[3] L.A. Oro, M.T. Pinillos, C. Tejel, J. Organomet. Chem. 280 (1985) 261.

[4] M.T. Youinou, R. Ziessel, J. Organomet. Chem. 363 (1989) 197.

[5] M. Ciriano, F. Viguri, J.J. Perez-Torrente, F.J. Lahoz, L.A. Oro, A. Tiripicchio, M. Tiripicchio-Camellini, J. Chem. Soc., Dalton Trans. (1989) 25.

[6] J.C. Bayon, G. Net, J. Real, R.J. Rasussen, J. Organomet. Chem. 385 (1990) 409.

[7] R. Halesha, N.M.N. Gowda, G.K.N. Reddy, Indian J. Chem., Sect. A 29 (1990) 661.

[8] G. Garcia, G. Sanchez, I. Romero, I. Solano, M.D. Santana, G. Lopez, J. Organomet. Chem. 408 (1991) 241.

[9] E.C. Constable, Polyhedron 7 (1984) 1037.

[10] D.W. Evans, G.R. Baker, G.R. Newkome, Coord. Chem. Rev. 93 (1989) 155.

[11] I. Omae, Coord. Chem. Rev. 83 (1988) 137.

[12] M.I. Bruce, Angew. Chem., Int. Ed. Eng. 16 (1977) 73.

[13] P.J. Steel, J. Organomet. Chem. 408 (1991) 395.

[14] A. Zilan, U. Maeder, A.V. Zelewski, H.V. Gudel, J. Am. Chem. Soc. 111 (1989) 3855.

[15] M. Nanoyama, J. Organomet. Chem. 74 (1974) 115.

[16] M. Nanoyama, J. Organomet. Chem. 92 (1975) 89.

[17] A.D. Rybov, Chem. Rev. 90 (1990) 403.

[18] S. Ruttimann, G. Bernardinelli, A.F. Williams, Angew. Chem. Int., Ed. Eng. 32 (1993) 392.

[19] V. Gayathri, E.G. Leelamani, N.M.N. Gowda, G.K.N. Reddy, Polyhedron 16 (1997) 1169

[20] V. Gayathri, N. Shashikala, N.M.N. Gowda, G.K.N. Reddy, Indian J. Chem. Sect. A 32 (1993) 33.

[21] G.K.N. Reddy, E.G. Leelamani, Current Science 34 (1965) 146.

[22] R. Bothner-By, R.L. Stephens, I.M. Lee, C.D. Warren, J. Jeanluz, J. Am. Chem. Soc. 106 (1984) 811.

[23] A. Bax, D.G. Davis, J. Magn. Reson. 63 (1985) 207.

[24] J.R. Ferraro (Ed.), Low Frequency Vibrations and Inorganic and Coordination Compounds, Plenum Press, New York, 1977, p. 111.

[25] W. Keim, J. Organomet. Chem. 14 (1968) 179.

[26] I.C.M. Wehman-Ooyevar, J.A. Vedral, J.T.B.H. Jastrzebski, D.M. Grove, G. Van Koten, J. Organomet. Chem. 451 (1993) 195.

[27] A.R. Garber, P.E. Garrou, G.E. Hartwell, M.J. Smas, J.R. Wilkinson, L.J. Todd, J. Organomet. Chem. 86 (1975) 219.

[28] R.J. Foot, B.T. Heaton, J. Chem. Soc., Dalton Trans. (1979) 295.

[29] A.P.B. Lever (Ed.), Inorganic Electronic Spectroscopy, Elsevier, Amsterdam, 1984, p. 464.

[30] N.M.N. Gowda, S.B. Naikar, G.K.N. Reddy, Adv. Inorg. Chem. Radiochem. 28 (1984) 255.

[31] X. Xiamoming, M. Haga, T. Matsumura-Inoue, Y. Ru, A.W. Addison, K. Kano, J. Chem. Soc., Dalton Trans. (1993) 2477. 